OPEN ACCESS

Edited by:

Giovanna Schiavoni,

National Institute of Health (ISS), Italy

Reviewed by:

Olga Krysko,

Ghent University, Belgium

Oliver Kepp,

Institut National de la Santé et de la

Recherche Médicale (INSERM),

France

Jonathan Pol,

Institut National de la Santé et de la

Recherche Médicale (INSERM),

France

*Correspondence:

Luis E. Muñoz

Iuis.munoz@fau.de

Specialty section:

This article was submitted to Cancer Immunity and Immunotherapy,

a section of the journal

Frontiers in Oncology

Received: 05 February 2021

Accepted: 29 July 2021

Published: 16 August 2021

Citation:

Podolska MJ, Shan X, Janko C, Boukherroub R, Gaip/ US, Szunerits S,

Frey $B$ and Muñoz LE (2021)

Graphene-Induced Hyperthermia

(GIHT) Combined With Radiotherapy

Fosters Immunogenic Cell Death.

Front. Oncol. 11:664615.

doi: 10.3389/fonc.2021.664615

\section{Graphene-Induced Hyperthermia (GIHT) Combined With Radiotherapy Fosters Immunogenic Cell Death}

\author{
Malgorzata J. Podolska ${ }^{1,2}$, Xiaomei Shan ${ }^{1,2}$, Christina Janko ${ }^{3}$, Rabah Boukherroub ${ }^{4}$, \\ Udo S. Gaipl ${ }^{5}$, Sabine Szunerits ${ }^{4}$, Benjamin Frey ${ }^{5}$ and Luis E. Muñoz ${ }^{1,2 *}$ \\ ${ }^{1}$ Department of Internal Medicine 3 - Rheumatology and Immunology, Friedrich-Alexander-University of Erlangen-Nürnberg \\ (FAU), Universitätsklinikum Erlangen, Erlangen, Germany, ${ }^{2}$ Deutsches Zentrum für Immuntherapie (DZI), Friedrich-Alexander- \\ University Erlangen-Nürnberg and Universitätsklinikum Erlangen, Erlangen, Germany, ${ }^{3}$ Department of Otorhinolaryngology, \\ Head and Neck Surgery, Section of Experimental Oncology and Nanomedicine (SEON). Else Kröner-Fresenius-Stiftung \\ Professorship, Universitätsklinikum Erlangen, Erlangen, Germany, ${ }^{4}$ Univ. Lille, CNRS, Centrale Lille, Univ. Polytechnique \\ Hauts-de-France, UMR 8520-IEMN, Lille, France, ${ }^{5}$ Translational Radiobiology, Department of Radiation Oncology, \\ Universitätsklinikum Erlangen, Friedrich-Alexander-Universität Erlangen-Nürnberg (FAU), Erlangen, Germany
}

Radiotherapy and chemotherapy are the standard interventions for cancer patients, although cancer cells often develop radio- and/or chemoresistance. Hyperthermia reduces tumor resistance and induces immune responses resulting in a better prognosis. We have previously described a method to induce tumor cell death by local hyperthermia employing pegylated reduced graphene oxide nanosheets and near infrared light (graphene-induced hyperthermia, GIHT). The spatiotemporal exposure/release of heat shock proteins (HSP), high group mobility box 1 protein (HMGB1), and adenosine triphosphate (ATP) are reported key inducers of immunogenic cell death (ICD). We hypothesize that GIHT decisively contributes to induce ICD in irradiated melanoma B16F10 cells, especially in combination with radiotherapy. Therefore, we investigated the immunogenicity of GIHT alone or in combination with radiotherapy in melanoma B16F10 cells. Tumor cell death in vitro revealed features of apoptosis that is progressing fast into secondary necrosis. Both HSP70 and HMGB1/DNA complexes were detected 18 hours post GIHT treatment, whereas the simultaneous release of ATP and HMGB1/ DNA was observed only 24 hours post combined treatment. We further confirmed the adjuvant potential of these released DAMPs by immunization/challenge experiments. The inoculation of supernatants of cells exposed to sole GIHT resulted in tumor growth at the site of inoculation. The immunization with cells exposed to sole radiotherapy rather fostered the growth of secondary tumors in vivo. Contrarily, a discreet reduction of secondary tumor volumes was observed in mice immunized with a single dose of cells and supernatants treated with the combination of GIHT and irradiation. We propose the simultaneous release of several DAMPs as a potential mechanism fostering anti-tumor immunity against previously irradiated cancer cells.

Keywords: reduced graphene oxide, immunogenic cell death, hyperthermia, multimodal, radiotherapy, melanoma 


\section{INTRODUCTION}

Every anti-tumor therapy aims to induce immunogenic cell death (ICD), which favors the development of specific antitumor responses. The spatiotemporal exposure of calreticulin on the outer leaflet of the plasma membrane $(1,2)$, the secretion of ATP $(3,4)$, and the release of DAMPs such as HMGB1 (4-6), heat shock protein $70(\operatorname{HSP} 70)(7,8)$ and $\operatorname{HSP} 90(4,9)$ are essential organic adjuvants required to induce ICD. These signals are recognized by various pattern recognition receptors on antigen presenting cells facilitating their activation and migration to draining lymph nodes followed by induction of potent adaptive immune response (10). The presence of one of the organic adjuvants is not sufficient to induce proper immune reactions and must be accompanied by additional signals. We have postulated that the release from dead cells of both 'find-me' (ATP) and danger signals (HMGB1 and HSP90) is enough to support robust immune responses, whereas when only one of the adjuvants concurs, anti-tumor immunity fails (4). Some mediators released by dying cells, such as Prostaglandin E2 or adenosine, show immunosuppressive features contributing to the tolerance $(11,12)$ and growth of tumor cells (13).

Besides sensitizing tumor cells to radio- and chemotherapy (14), hyperthermia has been demonstrated to have a direct cell killing effect (apoptosis or necrosis) in both in vitro and in vivo conditions (15-17). This is achieved by the denaturation and aggregation of intracellular proteins that are not seen in the case of radio- or chemotherapies (18-22). Temperatures above $44^{\circ} \mathrm{C}$ cause extensive cell damage due to sudden protein aggregation and result in necrosis, whereas apoptosis is usually elicited in the case of moderate hyperthermia (i.e., $\left.41.5^{\circ} \mathrm{C}\right)(23,24)$. There are hints that the mode of action inducing the heat has a decisive effect on the cell death (25). Nuclear proteins and components of the Mre11-Rad50-Nbs1 complex orchestrating the repair of double strand breaks in DNA are the most prone to heat-induced degradation (26-29). Hence, the energy dose (temperature) and time jointly orchestrate the systemic outcome. This means that the generation and control of the heat are essential parameters to be modulated. With the lack of instruments assuring homogenous heat dispersion, profound damage can be induced to the surrounding tissues. The prevention of the latter and targeting invisible metastasis are the main challenges of this field and are still under development. Although shrinking tumors, sole hyperthermia cannot substitute any actual therapy (30). Nevertheless, hyperthermia is undoubtedly sensitizing tumor cells for further treatments $(25,31-33)$.

Gamma irradiation induces irreversible double-strand DNA breaks leading to apoptotic cell death. Dying tumor cells in vivo are sensed by the immune system propagating predominantly tolerogenic messages (34-36). Whether hyperthermia complementing radiotherapy results in ICD has not been investigated in-depth yet. We have recently shown that PEGylated reduced graphene oxide nanosheets (rGO-PEG) are biocompatible, non-toxic, and can be used for intravenous application to induce fine-tuned localized hyperthermia by application of near infrared radiation (37). We demonstrate herein that tumor cells killed by the combination of gamma irradiation and hyperthermia release several
DAMPs in a fashion that renders dead B16F10 melanoma cells immunogenic.

\section{MATERIALS AND METHODS}

\section{Gamma Irradiation ( $\mathrm{X}$ rays)}

B16F10 melanoma cells derived from the C57BL/6 mouse (ATCC, \#CRL-6475) were exposed to ionizing irradiation (20 Gy, 120 kV, 22.7 mA; GE Inspection Technologies, Germany).

\section{Graphene-Induced Hyperthermia (GIHT)}

B16F10 melanoma cells were exposed to GIHT as described before (37). The cells were seeded in 24-well flat-bottom culture plates $\left(2 \times 10^{5}\right.$ cells/well). Next, graphene nanosheets $(50 \mu \mathrm{g} / \mathrm{ml})$ were placed in transwell inserts $(0.4 \mu \mathrm{m}$ pores) in close proximity to the cells, and plates were exposed to near-infrared irradiation (NIR, $960 \mathrm{~nm}, 1$ hour, $2 \mathrm{~W} / \mathrm{cm}^{2}$ ) applied by Hydrosun ${ }^{\circledR} 750$ (Hydrosun Medizintechnik, Müllheim, Germany). The lower compartment's temperature was registered every $10 \mathrm{~s}$ with a Voltcraft K204 Thermometer (Voltcraft, Wollerau, Switzerland) and a high sensitive "in-well" temperature probe.

\section{Flow Cytometric Analysis of Cell Death}

The supernatants (SNs) containing detached B16F10 melanoma cells treated with X-ray irradiation, GIHT, or a combination of both were collected 24 hours post treatment into polypropylene tubes. Remaining adherent cells were exposed to trypsin-EDTA solution for $5 \mathrm{~min}$ at room temperature (RT), and detached cells were added to their corresponding $\mathrm{SN}$ fractions. Cells kept at $37^{\circ} \mathrm{C}$ and $5 \% \mathrm{CO}_{2}$ served as control of cell death and normal cell turnover. Harvested cells were centrifuged at $300 \times \mathrm{g}$ for $5 \mathrm{~min}$, and a morphophysiological characterization of cell death by flow cytometry measurement was performed as described before (38). Briefly, the cells were resuspended in a four-color staining solution containing 1 $\mu \mathrm{g} / \mathrm{ml}$ of Annexin A5 (AxA5)-FITC (ImmunoTools, Friesoythe, Germany), $100 \mathrm{ng} / \mathrm{ml}$ of PI (Sigma-Aldrich, Taufkirchen, Germany), $10 \mathrm{nM}$ 1,1',3,3,3',3'-hexamethylindodicarbo - cyanine iodide (DiIc1(5), Enzo Life Sciences, Lörrach, Germany), $1 \mu \mathrm{g} / \mathrm{ml}$ of Hoechst 33342 (Thermo Fisher Scientific Inc., Waltham, USA) in Ringer's solution for $30 \mathrm{~min}$ at RT followed by acquisition on Gallios flow cytometer and analysis with the software Kaluza 2.1.

\section{Detection of Danger Signals}

Plates containing treated B16F10 melanoma cells and specified controls were centrifuged at $300 \mathrm{xg}$ for $5 \mathrm{~min}$ at the indicated time points, and the SNs were collected. The release of ATP from B16F10 melanoma cells was detected with the 'Luminescent ATP Detection Assay Kit' (Abcam, Cambridge, UK). ATP degradation was prevented by the provided lysis buffer. Luminescence measurements were performed on a Centro LB960 luminometer. HMGB1 and HSP70 were detected with the HMGB1 ELISA Kit II (IBL International, Hamburg, Germany) and DuoSet IC Kit (R\&D Systems (Minneapolis, USA), respectively, according to the manufacturer's instructions. For the measurement of absorbance, an ELISA Microplate Reader and the software Magellan 7.1 SP1 were used. 


\section{Splenocytes Isolation and Staining}

Briefly, Balb/c mice were sacrificed, and dissected spleens were pressed through a $70 \mu \mathrm{m}$ cell strainer washed with ice-cold PBS. Collected cells were centrifuged at $300 \mathrm{xg}$ for $5 \mathrm{~min}$ at $4^{\circ} \mathrm{C}$. Erythrocytes were lysed with erythrocytes lysis buffer for $2 \mathrm{~min}$, followed by centrifugation at $300 \mathrm{xg}$ for $5 \mathrm{~min}$ at $4^{\circ} \mathrm{C}$. Splenocytes proliferation was detected with the CellTrace ${ }^{\mathrm{TM}}$ CFSE Cell Proliferation Kit (Thermo Fisher Scientific, Rockford, USA) employed according to the manufacturer's instructions. In brief, splenocytes (10e6 cells/ml) were incubated in $5 \mu \mathrm{M}$ staining solution for $20 \mathrm{~min}$ at RT. Excessive dye was removed by adding the medium with $10 \%$ serum for $5 \mathrm{~min}$ at RT. Next, labeled cells were centrifuged at $300 \mathrm{xg}$ for $5 \mathrm{~min}$ and were employed in further experiments.

\section{Dendritic Cell Generation and Activation}

Femora and tibia bones from sacrificed C57BL/6 mice were sterilized in $70 \%$ ethanol. Next, bone marrow was washed out with a needle $(0.4 \mathrm{~mm} \times 19 \mathrm{~mm})$ into ice-cold medium. Collected cells were filtered through a $70 \mu \mathrm{m}$ cell strainer and centrifuged at $300 x$ for $5 \mathrm{~min}$ at $4^{\circ} \mathrm{C}$. Bone marrow-derived cells were differentiated with a complete cell culture medium containing $4 \mathrm{ng} / \mathrm{ml}$ of GM-CSF (ImmunoTools, Friesoythe, Germany) and $10 \mathrm{ng} / \mathrm{ml} \mathrm{IL-4}$ (ImmunoTools, Friesoythe, Germany) for 7 days. On days 3 and 5, a fresh DCs medium was added. DC cultures were treated with $100 \mu \mathrm{l}$ of SNs from B16F10 melanoma cells treated with X-ray irradiation, GIHT, or a combination of both for 24 hours at $37^{\circ} \mathrm{C}$ and $5 \% \mathrm{CO}_{2}$. The expression of co-stimulatory molecules on DCs was confirmed after the conditioning treatment by flow cytometry using the following antibodies anti-mouse MHC II (1:600, Biolegend, San Diego, USA), anti-mouse CD11c (1:800, Biolegend, San Diego, USA), CD40 (1:800, Biolegend, San Diego, USA), CD86 (1:400, Biolegend, San Diego, USA).

\section{T Cell Activation and Proliferation}

Conditioned DCs were irradiated (20 Gy) and co-incubated with CFSE-stained splenocytes for four days, at $37^{\circ} \mathrm{C}$ and $5 \% \mathrm{CO}_{2}$. After 4 days splenocytes were stained with anti-mouse CD3 (1:400, Thermo Fisher Scientific, Rockford, USA), anti-mouse CD4 (1:600, Biolegend, San Diego, USA), and anti-mouse CD8 (1:800, Biolegend, San Diego, USA) antibodies added for $30 \mathrm{~min}$ at RT in the dark and analyzed with Gallios flow cytometer and the software Kaluza 2.1. The mean fluorescence intensity (MFI) of $\mathrm{T}$ cells exposed to unprimed DCs was used as the maximal signal to calculate the dilution of the dye induced by proliferation. The average number of divisions (division index) was obtained by dividing the maximal MFI signal by the signal obtained from $\mathrm{T}$ cells exposed to DCs pre-incubated with the indicated conditions.

\section{Mice}

All mice experiments were conducted in full agreement with institutional guidelines on animal welfare and with the approval of the local Animal Care and Use Committees of the University Erlangen-Nürnberg and the 'Regierung von Unterfranken' [Allowance numbers TS-12/2015 (bone marrow cells and splenocytes); 55.2 DMS-2532-2-103 (airpouch model); 54-2532.16/12 (tumor growth)].

\section{Air-Pouch Model}

Briefly, $5 \mathrm{~mL}$ of sterile air was injected subcutaneously in the back of previously anesthetized mice (isofluorane). The air formed a cavity between the skin and the fascia of the back of the thorax. This cavity was stabilized with $3 \mathrm{ml}$ of sterile air after three days. After five days the cellular membrane formed allows the study and quantification of infiltrating leukocytes. On day five, $5 \mathrm{~mL}$ of supernatants collected 24 hours post-treatment from B16F10 melanoma cells treated with X-ray irradiation, GIHT, or a combination of both were injected into airpouches. After 24 hours, the mice were sacrificed, and the lavage of pouches was collected. Lavages were centrifuged for $5 \mathrm{~min}$ at 300x $\mathrm{g}$ and stained for $30 \mathrm{~min}$ at room temperature in the dark with the following antibodies: $\alpha$-ms CD45 (Biolegend, San Diego, USA), $\alpha$-ms CCR3 (Biolegend, San Diego, USA), $\alpha$-ms CD11b (Thermo Fisher Scientific, Rockford, USA), $\alpha$-ms Ly-6C (Biolegend, San Diego, USA), $\alpha-\mathrm{ms}$ Ly-6G (Biolegend, San Diego, USA), $\alpha$-ms CD170 (Siglec-F) (Biolegend, San Diego, USA), $\alpha$-ms CD115 (Biolegend, San Diego, USA), $\alpha$-ms F4/80 (Biolegend, San Diego, USA). Fluorescence was measured on a Gallios cytofluorometer, and data analysis was performed with the software Kaluza 2.1 Following populations were distinguished: inflammatory monocytes (CD45pos CD11bpos Ly6Chigh Ly6Gneg CCR3neg SiglecFneg), anti-inflammatory monocytes (CD45pos CD11bpos Ly6Clow Ly6Gneg CCR3neg SiglecFneg), macrophages (CD45pos CD11bpos CD115pos F4/ 80pos), neutrophils (CD45pos CD11bpos Ly6Cpos Ly6Gpos CCR3neg SiglecFneg).

\section{Evaluation of the Efficiency of the Killing Method}

In order to determine whether supernatants of treated cells contained surviving cells that might preclude their use as immunization agent, supernatants containing detached dead and dying cells were transferred to a new culture flask containing fresh DMEM supplemented with 10\% (v/v) FBS and penicillin-streptomycin and cultured at $37^{\circ} \mathrm{C}$ in a $5 \% \mathrm{CO}_{2}$ atmosphere. Cell survival and ability to form colonies were investigated 7 days post-transfer. Microphotographs were taken on Microscope Axiovert 25 by a Nikon D700 reflex camera. Images were processed using Adobe Photoshop CS5. Also C57BL/6 mice were injected intraperitoneally (i.p.) with supernatants of treated cells. Mice were sacrificed once tumor growth in the peritoneal cavity was detected by simple inspection and palpation. The experiment ended at 32 days, and surviving mice were sacrificed. Results are presented as Kaplan-Meier survival curves (Figure 2).

\section{Anti-Tumor Immunization}

A syngeneic anti-tumor immunization model was used. Mice (C57BL/6, MHC haplotype $\mathrm{H} 2 \mathrm{~b}$ ) were immunized i.p. with supernatants containing detached dead and dying cells harvested 24 hours post-treatment from B16F10 melanoma cells (carriers of the MHC haplotype $\mathrm{H} 2 \mathrm{~b}$ ). SNs from cells treated with gamma irradiation or the combination of GIHT and gamma irradiation were used in this experiment. GIHT alone was not used as immunization since the inoculum 
contained surviving cells and was not suitable as an immunization agent (Figure 2). After 14 days, the mice were challenged subcutaneously (s.c.) in the back with viable B16F10 melanoma cells $\left(1 \times 10^{6}\right)$. The width, height, and depth of subcutaneous tumors were measured with a caliper and recorded for a maximum 16 days.

\section{Statistics}

Statistical analysis was performed by GraphPad Prism (version 7.0) software. As statistically significant, the p-values $\leq 0.05$ were considered.

\section{RESULTS}

\section{GIHT Triggers Apoptosis Rapidly Followed by Secondary Necrosis}

Anti-tumor therapies induce various types of cell death that might result either in the activation or in the inhibition of specific anti-tumor immune responses. For example, the survival of cancer patients has been negatively correlated with tolerogenic apoptosis (39), and primary necrosis was shown to lack of immunogenicity (4). Therefore, we first evaluated the type of cell death induced by GIHT, gamma irradiation and its combination in vitro employing a flow cytometry-based sixparameter classification protocol (Supplementary Figures 1, 2) (38). Untreated cells display a high proportion of viable cells (Figure 1). The exposure of B16F10 melanoma cells to gamma irradiation alone results mainly in primary necrosis independently of GIHT (Figure 1). NIR exposure caused hyperthermia and rapid progression to secondary necrosis when rGO or rGO-PEG were present (GIHT, Supplementary Figure 2) (37). This phenotype persisted after the combined action of gamma-irradiation and GIHT (Figure 1).

\section{Surviving Cells Are Present in Supernatants of Dead and Dying Cells}

The stimulation of proliferation of few surviving cells by bystander dead cells has been confirmed for melanoma cells, fibroblasts, and primary synoviocytes (13) and it might contribute considerably to relapses after radio- or chemotherapy (40-42). In order to determine the suitability of dying tumor cells supernatants as immunization adjuvants, we further cultured supernatants containing detached dead and dying cells in culture flasks and in the peritoneal cavity of $\mathrm{C} 57 \mathrm{Bl} / 6$ mice. The supernatants of untreated cells and those treated with GIHT contained surviving cells that generated colonies after 7 days of cultures in vitro and tumors in the peritoneal cavity of mice, respectively (Figure 2). Contrarily, supernatants of cells treated with gamma irradiation and with the combination of irradiation and GIHT did not generate colonies in vitro or peritoneal tumors in vivo (Figure 2). This indicates that killing of B16F10 melanoma cells by hyperthermia alone might cause the release of growth and survival factors that support the growth of tumors at the site of injection of supernatants. This precludes the use of cells treated with hyperthermia alone in immunization protocols.

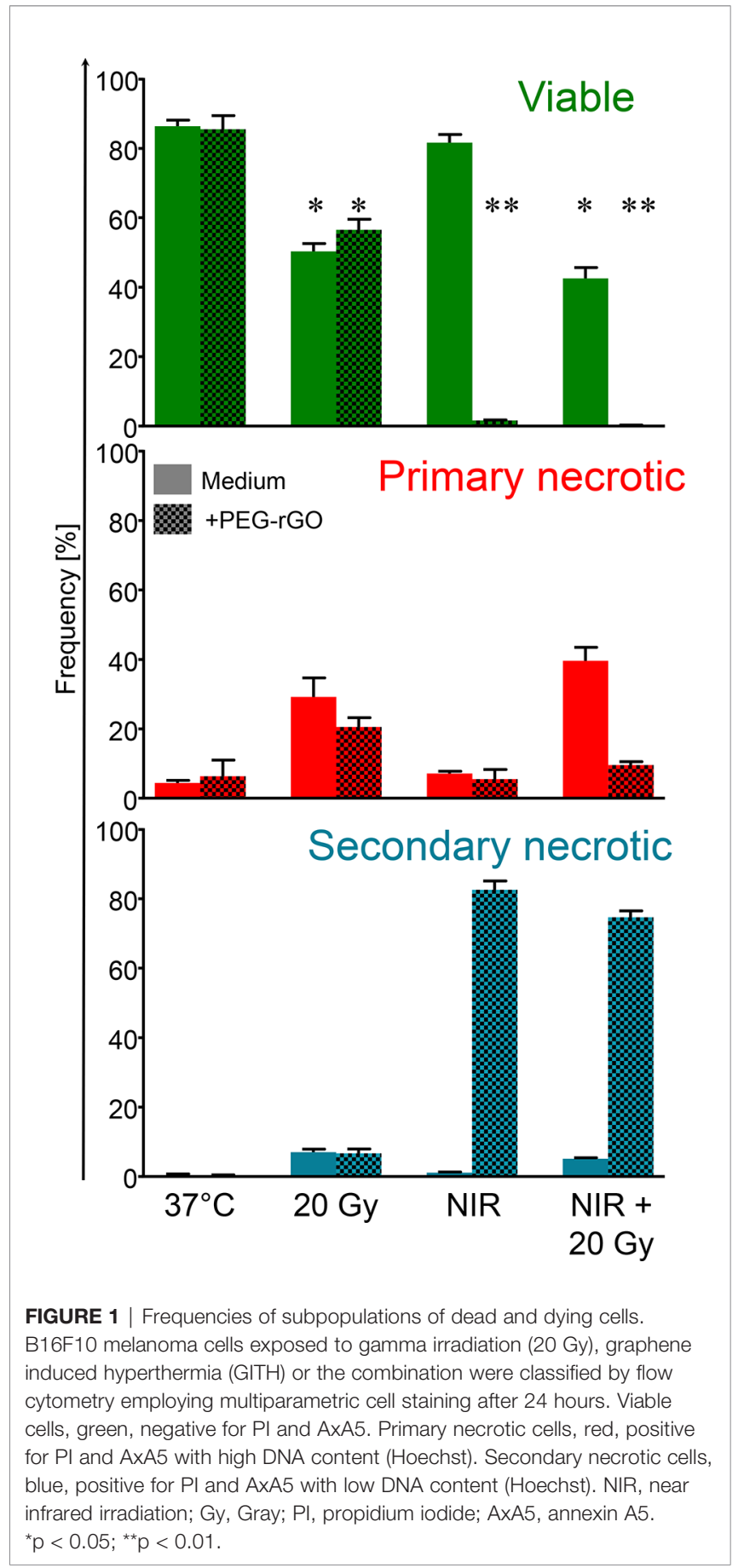

\section{Dying Cells Killed by GIHT Combined With Gamma Irradiation Induce Inflammatory Cell Infiltration in the Site of Injection}

Employing the in vivo airpouch model, we investigated the proinflammatory potential of mediators released by dead cells induced by GIHT alone or in the combination with gamma irradiation (Figure 3). Supernatants of dead and dying cells were injected into established sterile airpouches. We observed a significant increase in the infiltration of inflammatory 


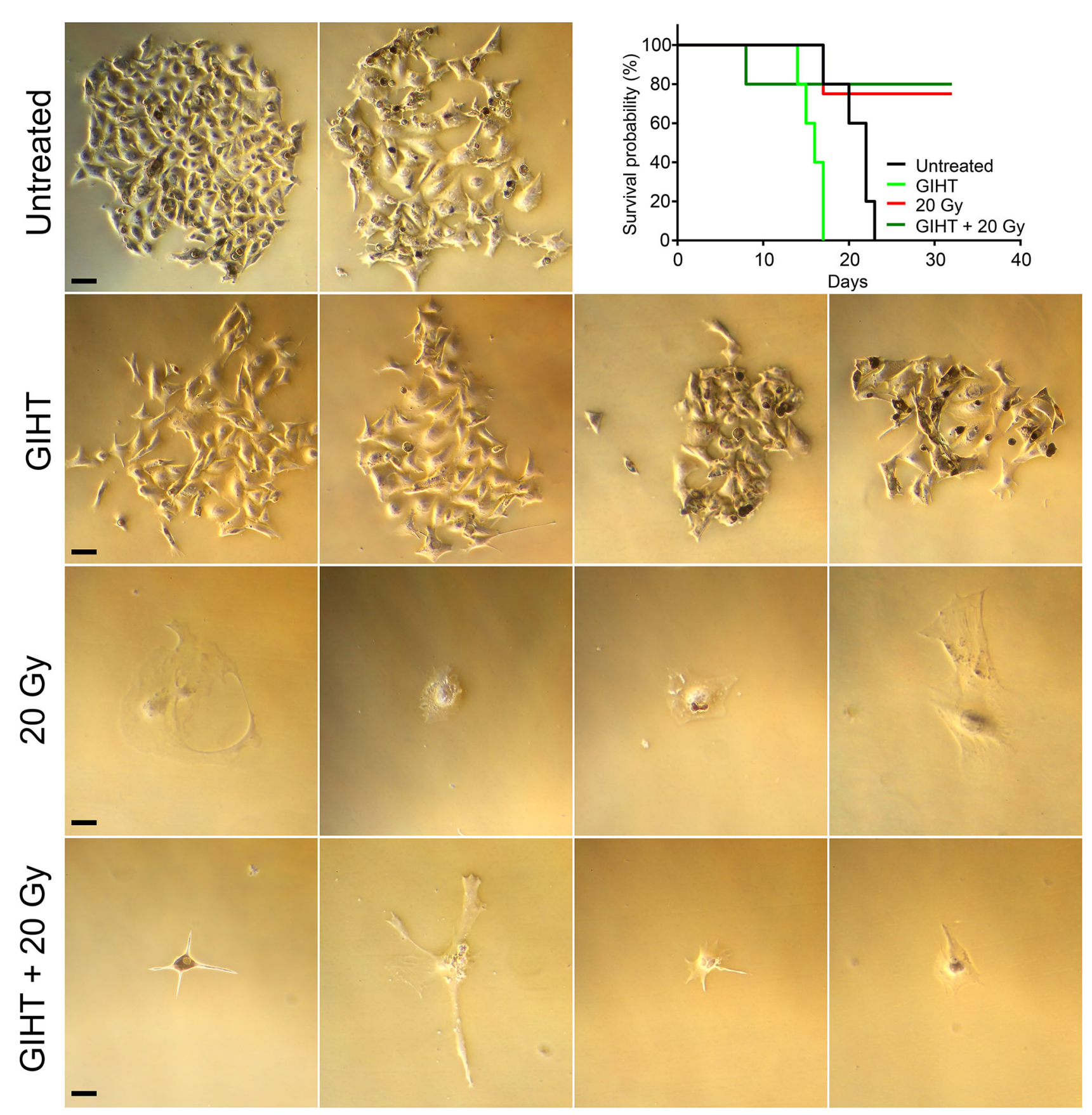

FIGURE 2 | Efficiency of cell killing. B16F10 melanoma cells exposed to gamma irradiation (20 Gy), GIHT or the combination. Supernatants containing detached dead and viable cells were collected 24 hours post-treatment and cultured for further 7 days adding fresh medium twice. Representative bright field pictures of cultures show growth of colonies after 7 days of treatment. Supernatants were also injected in the peritoneal cavity of C57BI/6 mice. Mice were observed during 32 days or euthanized before if the growing tumor compromised their wellbeing. Kaplan-Meier survival analysis of mice $(n=4$ or 5$)$ treated with the indicated supernatants. Scale bar, 25 m. Gy, Gray; GIHT, graphene induced hyperthermia; i.p. intraperitoneal.

neutrophils into airpouches supernatants induced by the combination of therapies accompanied by a significantly decreased proportion of anti-inflammatory monocytes and macrophages. Supernatants of irradiated cells caused a moderate elevation of inflammatory monocytes (Figure 3).

\section{GIHT Combined With Gamma Irradiation Elicits the Release of Organic Adjuvants With a Specific Spatiotemporal Pattern}

We further analyzed the presence of organic adjuvants released by dead and dying B16F10 melanoma cells after GIHT (37) 
(Figure 4). We observed an early ( $\mathrm{t} 0$ ) and late (t24) release of ATP in the case of GIHT applied alone or in combination with gamma irradiation (Figure 4A). Also, both treatments induced late release of HSP-70 (Figure 4B). However, only the combination of GIHT and 20 Gy was associated with a late secretion of HMGB-1 (Figure 4C), suggesting the release of nucleosome-bound HMGB-1 as reported for secondary necrotic cells (43).

\section{Dying Cells Treated With GIHT and $X$-Rays Induce the Proliferation of Naive T Cells In Vitro}

After confirming the presence of released organic adjuvants and testing its inflammatory potential, we aimed to investigate whether these adjuvants contribute to the activation of DCs. The supernatants of all treatments caused a significant upregulation of the activation markers CD80, CD86, MHC-II and CD40 on bone marrow derived DCs (Supplementary Figure 3). These conditionally activated DCs were used in a modified mixed lymphocyte reaction (MLR) to activate naive allogeneic $\mathrm{T}$ cells to proliferate (Figures 5A, B). The allogeneic major histocompatibility complex (MHC) molecules induced socalled background stimulation of $\mathrm{T}$ cells proliferation (Figures 5A, B, UNT). We observed that the proliferation of CD4+ T cells but not CD8+ T cells were significantly increased in response to $\mathrm{SN}$ from tumor cells exposed to GIHT alone or in combination with gamma irradiation (Figures 5A, B).

\section{Dying Cells Killed by GIHT Combined With Gamma Irradiation Elicit Specific Anti- Tumor Immune Responses In Vivo}

Once we observed that innate and adaptive immune activation was induced by the SN from tumor cells killed by the combination of hyperthermia and gamma irradiation, we sought to determine whether these $\mathrm{SN}$ are able to support specific anti-tumor responses if inoculated together with dead tumor cells in an immunization/challenge experiment. For this experiment we used the SN from untreated (containing no viable tumor cells), gamma irradiated alone (containing dead tumor cells) and in combination with GITH (containing dead tumor cells) as a single immunization dose. Mice were challenged with viable tumor cells after 14 days, and tumor growth was
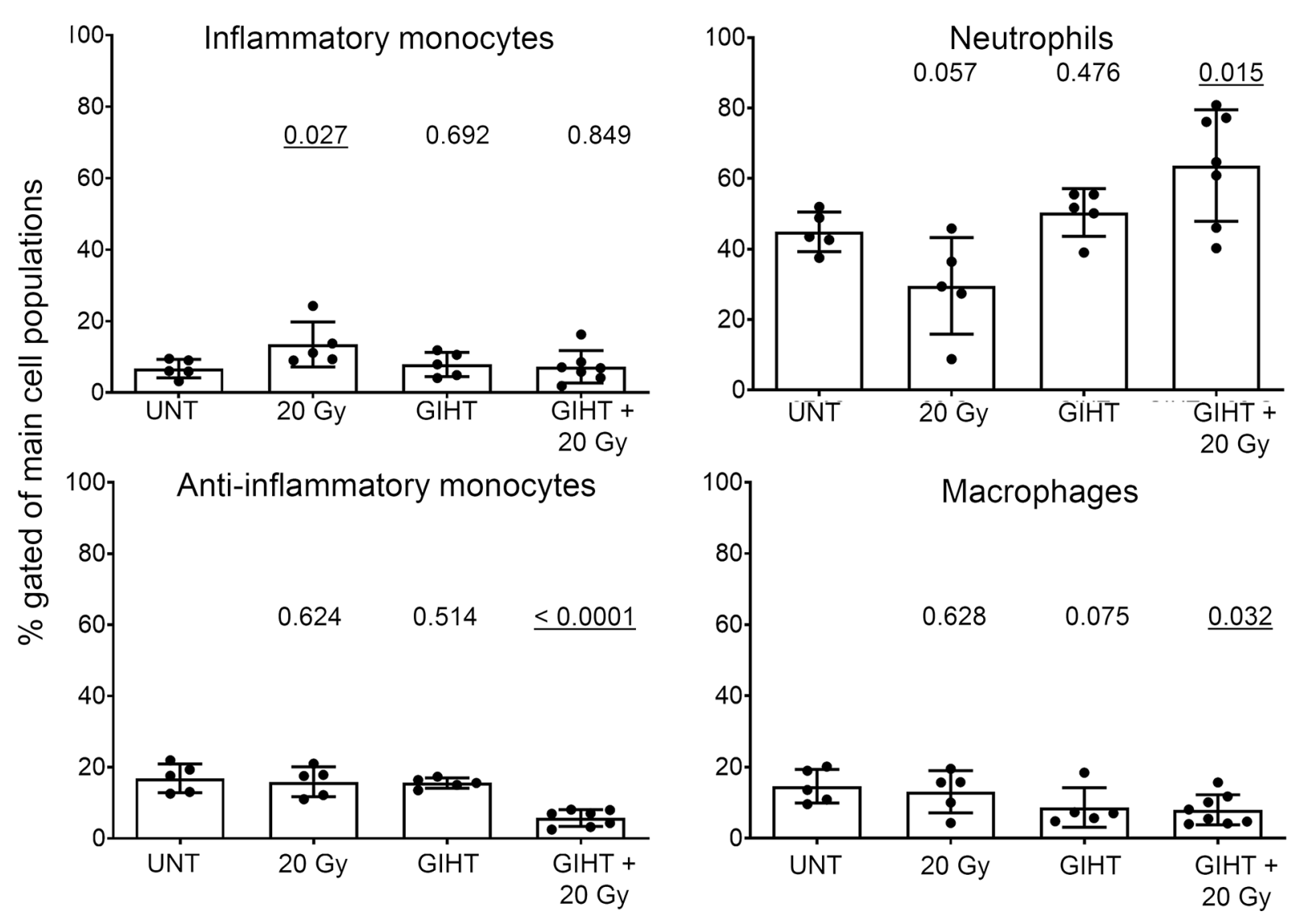

FIGURE 3 | Inflammatory cell infiltration to the site of cell death. SNs of dying B16F10 melanoma cells (24h) were injected into air pouches of mice and the infiltrating cells were quantified by flow cytometry. The infiltration caused by supernatants of untreated cells was used as a baseline. The main four myeloid populations are shown. One-way analysis of variances of five mice with Tukey's multiple comparison test is shown. Values of $p<0.05$ considered as significant are underlined. UNT, untreated; Gy, Gray; GIHT, graphene-induced hyperthermia. 
A

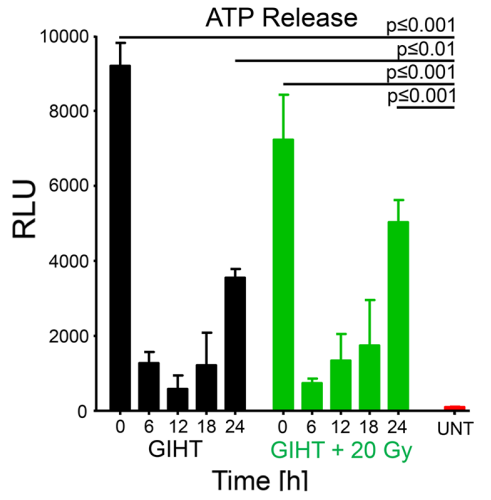

B

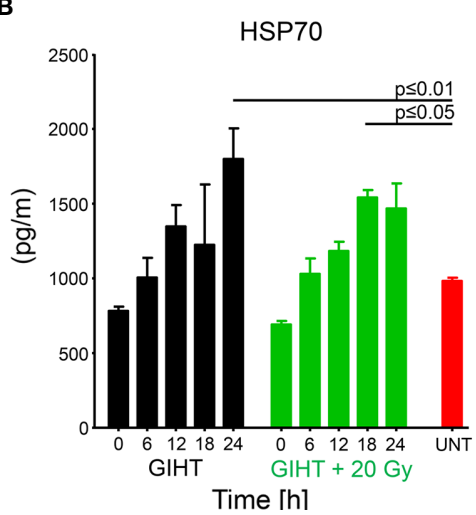

C

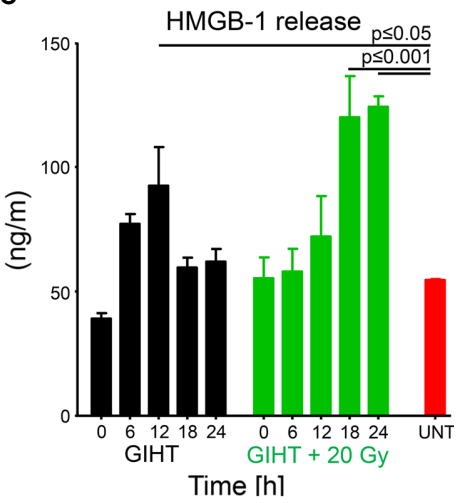

FIGURE 4 | Organic adjuvants released from GIHT treated B16F10 melanoma cells. (A) Time kinetic of the levels of ATP, (B) HSP70, and (C) HMGB-1 detected in supernatants after the application of the treatment. Supernatants from untreated cells (UNT) represent basal concentrations of DAMPs. The two-way analyses of variance with Bonferonni posttest was employed. Values of $\mathrm{p}<0.05$ were considered as significant. Means with the standard error of the mean (SEM) are shown. GIHT, graphene induced hyperthermia; UNT, untreated; ATP, adenosine triphosphate; HSP70, heat shock protein 70; HMGB1, high mobility group box 1 protein.

monitored for 32 days. The $\mathrm{SN}$ of cells exposed to the single treatment modality of gamma irradiation fostered the growth of secondary tumors while the combination of gamma irradiation and GITH resulted in a discreet reduction of the tumor volume of secondary tumors (Figures 5C-F and Supplementary Table 1).

\section{DISCUSSION}

Radiotherapy is an essential treatment option for the majority of patients bearing tumors (44). However, radioresistance of some cancer cells results in the failure of this therapy (45). Hyperthermia was demonstrated to radiosensitize tumor cells $(46,47)$. The effect of GIHT administered before radiation on the progression of cell death of the poorly immunogenic B16F10 melanoma cells was investigated. Twenty Gy resemble the two weeks cumulative dose of X-rays that patients receive when undergo radiotherapy (31).

We have observed that rGO and rGO-PEG exhibit the best photothermal conversion efficacy (37). The hyperthermia (42$43^{\circ} \mathrm{C}$ ) induced by rGO and rGO-PEG alone or in combination with gamma irradiation led to significantly increased cell death. When GIHT was administered alone or in combination with gamma irradiation, melanoma cells mainly followed apoptotic cell death patterns with fast progression to secondary necrosis. The decision taken by the dying cell is orchestrated by multiple factors, such as the severity of the damage, energy availability, the presence/absence of ligands of cell death/dependent receptors, or inhibitors of specific pathways. The outcome has profound effects on the subsequent immune response (48). Necrotic cell death does not always induce robust immune responses (4), and the activation of apoptosis might result as a double edge sword with features of immunogenic $(4,49,50)$ or tolerogenic (36) (40) cellular demise. Necroptotic cells, for example, although releasing 'find me' signals, may be engulfed without activating the immune system (51). Therefore, determining the precise death pathway and delineating its immunological consequences results of major importance while designing novel anticancer therapies.

When apoptotic cells are not cleared in an efficient and timely manner, they become secondary necrotic (52). In vivo, the complete apoptotic program's execution is usually interfered by rapid phagocytosis (53). However, in the case of large amounts of cell demise that challenges the capacity of phagocytes to efficiently clear cellular debris (54) or when the clearance capacity is itself reduced $(35,55)$, apoptotic cells lose their plasma membrane integrity and release immune stimulators $(56,57)$. Secondary necrosis in vivo is linked to multiple inflammatory and autoimmune disorders $(35,58,59)$. Based on our observations, we suggest that when GIHT is applied in combination with gamma irradiation, a large number of apoptotically modified tumor-derived antigens along with an appropriate cocktail of mediators are released and can stimulate DCs. This is possible due to the high frequency of secondarily necrotic cells observed with the multimodal therapy.

The efficiency of anti-cancer therapies rely on many factors. One of them is the microenvironment resulting directly after therapy. Massive cell death of solid tumors changes dramatically the tumor microenvironment and triggers biological reactions in the host and tumor. Inosine released by dead and dying cells mediates proliferation of surviving cells via purinergic receptors (13) and this might support the appearance of relapses $(40,42)$. The treatment with GITH alone was inefficient and fostered the rapid proliferation of surviving cells in our in vitro and in vivo settings.

It was demonstrated that the spatiotemporal appearance of organic adjuvants such as ATP (3, 4), HMGB1 (4-6), HSP70 (7, $8,60,61)$ and HSP90 $(4,9)$ decides about the consequences of cell demise. In line with this, we previously proposed that the sole presence of ATP leads to the silent removal of dead cells, whereas the presence of ATP together with HMGB1 or HSP90 induces the robust anti-tumor immune responses (4). 
A

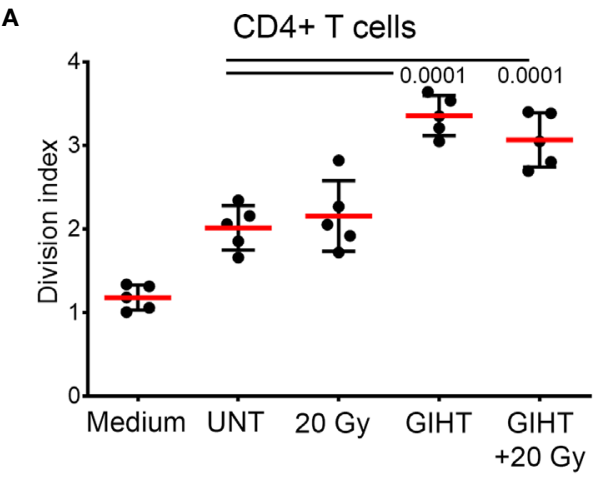

C

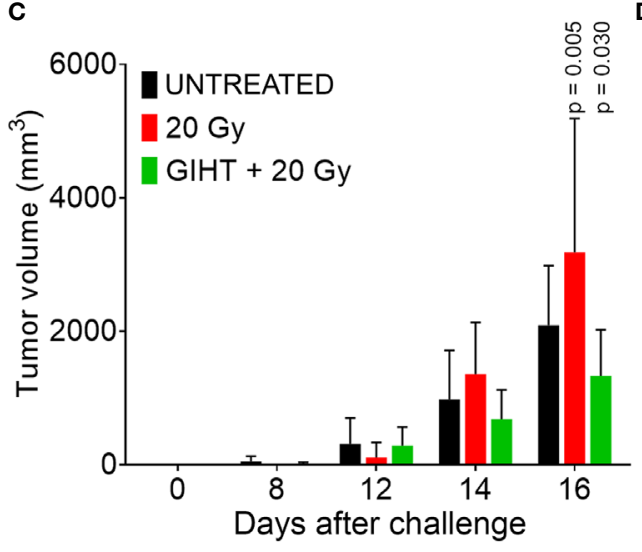

E

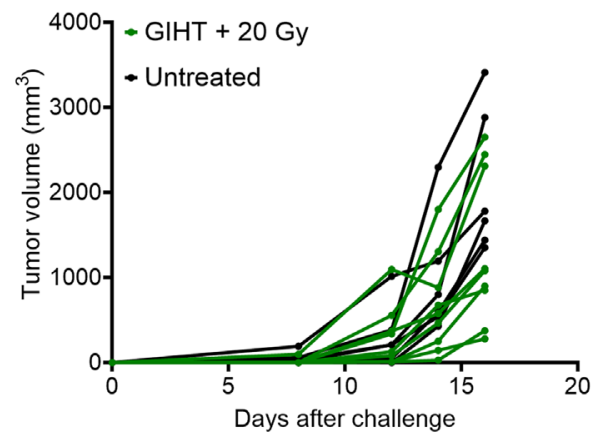

B

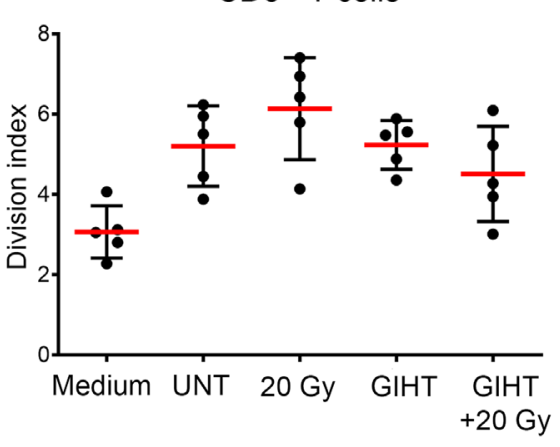

D

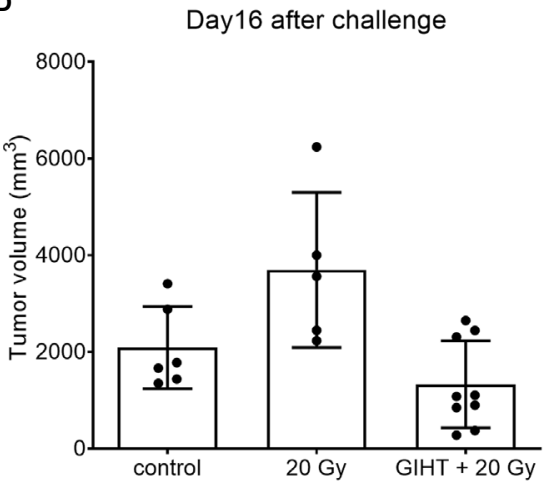

$\mathbf{F}$

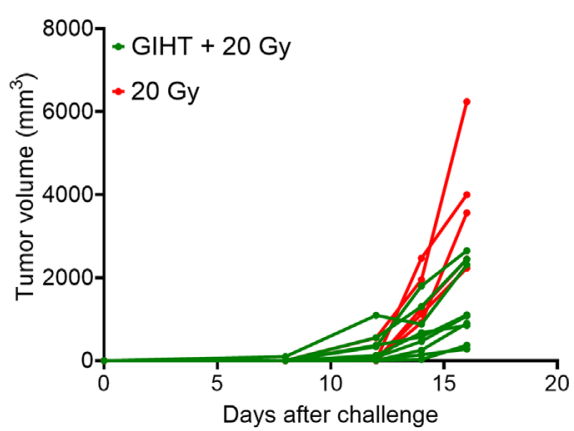

FIGURE 5 | Induction of specific anti-tumor immune responses. T cells proliferation induced by conditioned DCs. DCs were co-incubated for 24 hours with SN collected from B16F10 melanoma cells exposed to indicated treatments. CSFE-labelled T cells were co-cultured with DCs for 4 days. To show bottom-line proliferation, DCs were conditioned with fresh medium. Division index of CD4 positive T cells (A) and CD8 positive T cells (B) is shown. Kruskal-Wallis test with Dunn's multiple comparison test was employed. Values of $p<0.05$ were considered as significant. (C) Tumor growth after challenge of immunized mice. Immunization was performed with a single i.p. dosis of detached B16F10 melanoma cells including their supernantants. Fourteen days after the immunization, mice were challenged with viable B16F10 melanoma cells injected subcutaneously in the back. Two-way ANOVA was used to compare the means at each time point. Values of $p<0.05$ after Tukey's multiple comparison test were considered as significant and depicted. (D) Tumor volume of immunized mice at day 16 after the challenge with viable B16F10 melanoma cells. One way ANOVA was applied to evaluate the means at day 16 after challenge. (E, F) Tumor growth of single mice of the experiment shown in (C). P values of Fisher's least significant differences are depicted. Gy, Gray; GIHT, graphene-induced hyperthermia.

We detected significantly increased ATP release levels into the extracellular space mostly due to a temporal heatinduced permeability of membranes $(62,63)$, including mitochondrial envelopes. Notably, the recovery of plasma membranes occurs in the latest 40 minutes after the treatment since most of the cells are PI negative by this time point. The progression towards secondary necrosis was then responsible for the releases of further intracellular contents later on (24 hours).

We detected significantly increased secretion of HSP70 at 24 and 12 hours post administration of GIHT alone or combined with gamma irradiation, respectively. Exposure to 
elevated temperatures leads to the increased expression of intracellular HSP. Colorectal adenocarcinoma cells exposed to $41.5^{\circ} \mathrm{C}$ for 1 -hour show significantly decreased cell death orchestrated probably by the Thermo protection effect of HSP (64). In terms of ICD, when HSP proteins are presented on the plasma membrane's outer leaflet or are released in the extracellular milieu, they gain immune stimulatory properties $(7,8,60,61)$. In other studies, hyperthermia $\left(41.5^{\circ} \mathrm{C}, 1\right.$ hour) administered alone or in combination with radiation (2 Gy) was demonstrated to trigger the release of both proteins HSP70 and HMGB1 by dead and dying B16F10 melanoma cells (65). HSP70 secreted after the treatment elicits the maturation of DC and promotes the release of proinflammatory cytokines (64).

Chronic persistent inflammation is linked to tumorigenesis, and extracellular HMGB1 is perceived as a pro-inflammatory cytokine inducing the expression of other inflammatory factors (66-68). Besides that, HMGB1 leads to the secretion of other pro-inflammatory cytokines (i.e., TNF, IL-1, or IL-6) by resident or migrated leukocytes (69). In this manner, HMGB1 further fosters a vicious cycle of inflammation and manipulation of the immune system. The plethora of actions of HMGB1 can be explained by its redox status, the type of affected cell, and available receptors (70), as well as by its interaction with DNA. Free reduced HMGB1 protein was shown to be passively released by primary necrotic cells, whereas the oxidized form, which is additionally bound to the nucleosome, was observed in secondary necrotic cells (43, 71). It was reported that during apoptosis, cysteine residues of HMGB1 are oxidized by mitochondrial ROS produced in a caspase-dependent manner. This fosters immunological tolerance. Immunogenicity was then recovered by blocking its oxidation (72). Furthermore, apoptotic cell death accompanied by elevated intracellular levels of ROS exhibited higher immunogenicity in vivo when compared to the death developing in the absence of ROS (71).

In the death induced by GIHT alone, the release of danger signals was significantly increased at the earlier time points (HMGB1/DNA, 12 hours) when ATP was still absent. In the case of the combined treatments, we detected significant concentrations of extracellular DAMPs, HSP70, and HMGB1/ DNA, 18 hours post treatment. The combinational therapy was then characterized by the simultaneous increase of ATP and HMGB1/DNA released 24 hours post treatment. We have previously observed that dying cells are less potent stimulators when ATP is released without other DAMPs (4). The presence of only one of the organic adjuvants is not enough to provide sufficient stimulation of the immune system. Werthmöller et al. reported that the simultaneous presence of HSP70 and HMGB1 was linked to the increased immunogenic potential of cellular demise (65). This suggests that the DAMPs detected 18 hours post combinational treatment can stimulate the immune system. The additional presence of ATP further fosters the activation.

At the site of inoculation of supernatants, we observed significant infiltration of neutrophils and significantly decreased levels of anti-inflammatory monocytes in response to cells treated with GIHT combined with gamma irradiation. Single treatments affected less the composition of early infiltrates. It was demonstrated that dying cancer cells secrete specific chemokines to recruit cells of the immune system $(11,73)$. IL$1 \alpha$ and IL- $1 \beta$ were reported to attract neutrophils (initial phase) and macrophages (late phase) during sterile inflammation, respectively (74). Additionally, IL- $1 \alpha$ was shown to sustain chronic infiltration of neutrophils (75). After migration to the site of inflammation, exposure of neutrophils to 'eat me' signals, such as PS and calreticulin, results in the polarization to proinflammatory phenotype and, consequently, to cytotoxicity towards remaining cancer cells that survived the therapy (11). Therefore, we speculate that the observed infiltration of neutrophils might further support our multimodal therapy's anti-tumor potential.

Finally, we demonstrated that cell death induced by GIHT alone or in combination with gamma irradiation resulted in the activation of DCs, which stimulated the proliferation of CD4+ T cells in vitro. This suggests that released ATP and HMGB1-DNA complexes are potent supporters of $\mathrm{T}$ cell activation. Employing dead and dying cells in an immunization/challenge experiment, we observed a decreased tumor volume in the group of mice immunized with the combined treatment. Contrarily, gamma irradiation alone fails to induce protection against tumor growth. We suggest that the significant release of several DAMPs significantly contributes to increased immunogenicity of B16F10 melanoma cells. Therefore, GIHT could be implemented in multimodal therapies since it may take advantage of radio sensitization of tumor cells by inducing the timely release of ATP and HMGB1-DNA complexes during the progress of cell death.

The melanoma B16F10 clone implanted in immunocompetent syngeneic mice allows the study of tumor growth preserving the interactions between cancer cells and the microenvironment (76-78). However, this clone has the disadvantage to have a high proliferative and metastasizing capability (79) that precludes the use of viable cells for immunization. Therefore, the antigenic load at the immunization site might be insufficient to trigger immune responses that resulted in tumor free mice after the challenge. Nevertheless, our observations are significant enough to propose the study of the principle of radiosensitation using nanosheets-targeted hyperthermia in other solid tumors models in future research. When biocompatible rGO-PEG nanosheets are applied intravenously, they become enriched in well-vascularized tumors by the enhanced permeability and retention effect. These nanosheets can be then stimulated with deep penetrating NIR irradiation to achieve fine-tuned localized hyperthermia (GITH) in solid tumors.

\section{DATA AVAILABILITY STATEMENT}

The raw data supporting the conclusions of this article will be made available by the authors, without undue reservation. 


\section{ETHICS STATEMENT}

The animal study was reviewed and approved by Animal Care and Use Committees of the University Erlangen-Nürnberg and the 'Regierung von Unterfranken'.

\section{AUTHOR CONTRIBUTIONS}

Conceptualization, MP, CJ, BF, SS, and LM. Methodology, MP, $\mathrm{XS}, \mathrm{CJ}, \mathrm{BF}$, and RB. Software, MP, XS, and CJ. Validation, MP, CJ, SS, and LM. Formal analysis, MP, XS, CJ, BF, UG, and LM. Investigation, $\mathrm{MP}, \mathrm{CJ}, \mathrm{BF}$, and LM. Resources, RB, UG, SS, and LM. Data curation, MP, BF, UG, RB, CJ, and LM. Writing and original draft preparation, MP and LM. Writing-review and editing, MP, BF, UG, RB, SS, CJ, and LM. Visualization, MP, BF, CJ, and LM. Supervision, BF, SS, and LM. Funding acquisition, BF, SS, and LM. All authors contributed to the article and approved the submitted version.

\section{REFERENCES}

1. Obeid M, Panaretakis T, Joza N, Tufi R, Tesniere A, van Endert P, et al. Calreticulin Exposure is Required for the Immunogenicity of GammaIrradiation and UVC Light-Induced Apoptosis. Cell Death Differentiation (2007) 14:1848-50. doi: 10.1038/sj.cdd.4402201

2. Gardai SJ, McPhillips KA, Frasch SC, Janssen WJ, Starefeldt A, MurphyUllrich JE, et al. Cell-Surface Calreticulin Initiates Clearance of Viable or Apoptotic Cells Through Trans-Activation of LRP on the Phagocyte. Cell (2005) 123:321-34. doi: 10.1016/j.cell.2005.08.032

3. Elliott MR, Chekeni FB, Trampont PC, Lazarowski ER, Kadl A, Walk SF, et al. Nucleotides Released by Apoptotic Cells Act as a Find-Me Signal to Promote Phagocytic Clearance. Nature (2009) 461:282-6. doi: 10.1038/nature08296

4. Maueroder C, Chaurio RA, Dumych T, Podolska M, Lootsik MD, Culemann S, et al. A Blast Without Power - Cell Death Induced by the TuberculosisNecrotizing Toxin Fails to Elicit Adequate Immune Responses. Cell Death Differentiation (2016) 23:1016-25. doi: 10.1038/cdd.2016.4

5. Apetoh L, Ghiringhelli F, Tesniere A, Obeid M, Ortiz C, Criollo A, et al. TollLike Receptor 4-Dependent Contribution of the Immune System to Anticancer Chemotherapy and Radiotherapy. Nat Med (2007) 13:1050-9. doi: $10.1038 / \mathrm{nm} 1622$

6. Scaffidi P, Misteli T, Bianchi ME. Release of Chromatin Protein HMGB1 by Necrotic Cells Triggers Inflammation. Nature (2002) 418:191-5. doi: 10.1038/ nature 00858

7. Schildkopf P, Frey B, Ott OJ, Rubner Y, Multhoff G, Sauer R, et al. Radiation Combined With Hyperthermia Induces HSP70-Dependent Maturation of Dendritic Cells and Release of Pro-Inflammatory Cytokines by Dendritic Cells and Macrophages. Radiotherapy Oncol (2011) 101:109-15. doi: 10.1016/ j.radonc.2011.05.056

8. Song S, Zhou F, Chen WR, Xing D. PDT-Induced HSP70 Externalization UpRegulates NO Production via TLR2 Signal Pathway in Macrophages. FEBS Lett (2013) 587:128-35. doi: 10.1016/j.febslet.2012.11.026

9. Spisek R, Charalambous A, Mazumder A, Vesole DH, Jagannath S, Dhodapkar MV. Bortezomib Enhances Dendritic Cell (DC)-Mediated Induction of Immunity to Human Myeloma via Exposure of Cell Surface Heat Shock Protein 90 on Dying Tumor Cells: Therapeutic Implications. Blood (2007) 109:4839-45. doi: 10.1182/blood-2006-10-054221

10. Chen X, Li W, Ren J, Huang D, He WT, Song Y, et al. Translocation of Mixed Lineage Kinase Domain-Like Protein to Plasma Membrane Leads to Necrotic Cell Death. Cell Res (2014) 24:105-21. doi: 10.1038/cr.2013.171

11. Garg AD, Agostinis P. Cell Death and Immunity in Cancer: From Danger Signals to Mimicry of Pathogen Defense Responses. Immunol Rev (2017) 280:126-48. doi: 10.1111/imr.12574

\section{FUNDING}

This research was funded by the EU through the Marie Sklodowska-Curie action (H2020-MSCA-RISE-2015, PANG690836) and by the Manfred-Roth-Stiftung, Fürth, Germany.

\section{ACKNOWLEDGMENTS}

The authors acknowledge support by Deutsche Forschungsgemeinschaft (DFG) and Friedrich-Alexander Universität Erlangen-Nürnberg (FAU) within the funding program Open Access Publishing.

\section{SUPPLEMENTARY MATERIAL}

The Supplementary Material for this article can be found online at: https://www.frontiersin.org/articles/10.3389/fonc.2021.664615/ full\#supplementary-material

12. Galluzzi L, Bravo-San Pedro JM, Demaria S, Formenti SC, Kroemer G. Activating Autophagy to Potentiate Immunogenic Chemotherapy and Radiation Therapy. Nat Rev Clin Oncol (2017) 14:247-58. doi: 10.1038/nrclinonc.2016.183

13. Chen J, Chaurio RA, Maueroder C, Derer A, Rauh M, Kost A, et al. Inosine Released From Dying or Dead Cells Stimulates Cell Proliferation via Adenosine Receptors. Front Immunol (2017) 8:504. doi: 10.3389/fimmu.2017.00504

14. Hildebrandt B, Wust P, Ahlers O, Dieing A, Sreenivasa G, Kerner T, et al. The Cellular and Molecular Basis of Hyperthermia. Crit Rev Oncol/Hematol (2002) 43:33-56. doi: 10.1016/s1040-8428(01)00179-2

15. Dewey WC. Arrhenius Relationships From the Molecule and Cell to the Clinic. Int J Hyperthermia (2009) 25:3-20. doi: 10.1080/02656730902747919

16. Dewhirst MW, Prosnitz L, Thrall D, Prescott D, Clegg S, Charles C, et al. Hyperthermic Treatment of Malignant Diseases: Current Status and a View Toward the Future. Semin Oncol (1997) 24:616-25.

17. Urano M, Kuroda M, Nishimura Y. For the Clinical Application of Thermochemotherapy Given at Mild Temperatures. Int J Hyperthermia (1999) 15:79-107. doi: 10.1080/026567399285765

18. Dewey WC, Thrall DE, Gillette EL. Hyperthermia and Radiation-a Selective Thermal Effect on Chronically Hypoxic Tumor Cells In Vivo. Int J Radiat Oncol Biol Phys (1977) 2:99-103. doi: 10.1016/0360-3016(77)90013-X

19. Westra A, Dewey WC. Variation in Sensitivity to Heat Shock During the CellCycle of Chinese Hamster Cells In Vitro. Int J Radiat Biol Related Stud Physics Chemistry Med (1971) 19:467-77. doi: 10.1080/09553007114550601

20. Overgaard J, Suit HD. Time-Temperature Relationship Th Hyperthermic Treatment of Malignant and Normal Tissue In Vivo. Cancer Res (1979) 39:3248-53.

21. Sapareto SA, Raaphorst GP, Dewey WC. Cell Killing and the Sequencing of Hyperthermia and Radiation. Int J Radiat Oncol Biol Phys (1979) 5:343-7. doi: 10.1016/0360-3016(79)91214-8

22. Dewhirst MW, Vujaskovic Z, Jones E, Thrall D. Re-Setting the Biologic Rationale for Thermal Therapy. Int J Hyperthermia (2005) 21:779-90. doi: 10.1080/02656730500271668

23. Sakaguchi Y, Stephens LC, Makino M, Kaneko T, Strebel FR, Danhauser LL, et al. Apoptosis in Tumors and Normal Tissues Induced by Whole Body Hyperthermia in Rats. Cancer Res (1995) 55:5459-64.

24. Alekseenko LL, Zemelko VI, Zenin VV, Pugovkina NA, Kozhukharova IV, Kovaleva ZV, et al. Heat Shock Induces Apoptosis in Human Embryonic Stem Cells But a Premature Senescence Phenotype in Their Differentiated Progeny. Cell Cycle (2012) 11:3260-9. doi: 10.4161/cc.21595

25. Hader M, Frey B, Fietkau R, Hecht M, Gaipl US. Immune Biological Rationales for the Design of Combined Radio- and Immunotherapies. Cancer Immunol Immunother (2020) 69:293-306. doi: 10.1007/s00262-01902460-3 
26. Lepock JR, Frey HE, Heynen ML, Senisterra GA, Warters RL. The Nuclear Matrix is a Thermolabile Cellular Structure. Cell Stress Chaperones (2001) 6:136-47. doi: 10.1379/1466-1268(2001)006<0136:TNMIAT $>2.0$.CO;2

27. Lepock JR. Role of Nuclear Protein Denaturation and Aggregation in Thermal Radiosensitization. Int J Hyperthermia (2004) 20:115-30. doi: 10.1080/ 02656730310001637334

28. Roti Roti JL. Cellular Responses to Hyperthermia (40-46 Degrees C): Cell Killing and Molecular Events. Int J Hyperthermia (2008) 24:3-15. doi: $10.1080 / 02656730701769841$

29. Vidair CA, Dewey WC. Division-Associated and Division-Independent Hyperthermic Cell Death: Comparison With Other Cytotoxic Agents. Int J Hyperthermia (1991) 7:51-60. doi: 10.3109/02656739109004976

30. Wust P, Hildebrandt B, Sreenivasa G, Rau B, Gellermann J, Riess H, et al. Hyperthermia in Combined Treatment of Cancer. Lancet Oncol (2002) 3:48797. doi: 10.1016/S1470-2045(02)00818-5

31. Schildkopf P, Frey B, Mantel F, Ott OJ, Weiss E-M, Sieber R, et al. Application of Hyperthermia in Addition to Ionizing Irradiation Fosters Necrotic Cell Death and HMGB1 Release of Colorectal Tumor Cells. Biochem Biophys Res Commun (2010) 391:1014-20. doi: 10.1016/j.bbrc.2009.12.008

32. Issels RD. Hyperthermia Adds to Chemotherapy. Eur J Cancer (2008) 44:2546-54. doi: 10.1016/j.ejca.2008.07.038

33. Horsman MR, Overgaard J. Hyperthermia: A Potent Enhancer of Radiotherapy. Clin Oncol (R Coll Radiol) (2007) 19:418-26. doi: 10.1016/ j.clon.2007.03.015

34. Elliott MR, Ravichandran KS. Clearance of Apoptotic Cells: Implications in Health and Disease. J Cell Biol (2010) 189:1059-70. doi: 10.1083/ jcb.201004096

35. Gaipl US, Munoz LE, Grossmayer G, Lauber K, Franz S, Sarter K, et al. Clearance Deficiency and Systemic Lupus Erythematosus (SLE). J Autoimmun (2007) 28:114-21. doi: 10.1016/j.jaut.2007.02.005

36. Voll RE, Herrmann M, Roth EA, Stach C, Kalden JR, Girkontaite I. Immunosuppressive Effects of Apoptotic Cells. Nature (1997) 390:350-1. doi: $10.1038 / 37022$

37. Podolska MJ, Barras A, Alexiou C, Frey B, Gaipl U, Boukherroub R, et al. Graphene Oxide Nanosheets for Localized Hyperthermia-Physicochemical Characterization, Biocompatibility, and Induction of Tumor Cell Death. Cells (2020) 9(3):776. doi: 10.3390/cells9030776

38. Munoz LE, Maueroder C, Chaurio R, Berens C, Herrmann M, Janko C. Colourful Death: Six-Parameter Classification of Cell Death by Flow Cytometry-Dead Cells Tell Tales. Autoimmunity (2013) 46:336-41. doi: 10.3109/08916934.2012.755960

39. Gregory CD, Pound JD. Cell Death in the Neighbourhood: Direct Microenvironmental Effects of Apoptosis in Normal and Neoplastic Tissues. J Pathol (2011) 223:177-94. doi: 10.1002/path.2792

40. Chaurio R, Janko C, Schorn C, Maueroder C, Bilyy R, Gaipl U, et al. UVBIrradiated Apoptotic Cells Induce Accelerated Growth of Co-Implanted Viable Tumor Cells in Immune Competent Mice. Autoimmunity (2013) 46:317-22. doi: 10.3109/08916934.2012.754433

41. Cheng J, He S, Wang M, Zhou L, Zhang Z, Feng X, et al. The Caspase-3/ Pkcdelta/Akt/VEGF-a Signaling Pathway Mediates Tumor Repopulation During Radiotherapy. Clin Cancer Res (2019) 25:3732-43. doi: 10.1158/ 1078-0432.CCR-18-3001

42. Huang Q, Li F, Liu X, Li W, Shi W, Liu FF, et al. Caspase 3-Mediated Stimulation of Tumor Cell Repopulation During Cancer Radiotherapy. Nat Med (2011) 17:860-6. doi: 10.1038/nm.2385

43. Urbonaviciute V, Furnrohr BG, Meister S, Munoz L, Heyder P, De Marchis F, et al. Induction of Inflammatory and Immune Responses by HMGB1Nucleosome Complexes: Implications for the Pathogenesis of SLE. J Exp Med (2008) 205:3007-18. doi: 10.1084/jem.20081165

44. Ruckert M, Deloch L, Fietkau R, Frey B, Hecht M, Gaipl US. Immune Modulatory Effects of Radiotherapy as Basis for Well-Reasoned Radioimmunotherapies. Strahlenther Onkol (2018) 194:509-19. doi: 10.1007/s00066-018-1287-1

45. Gorayski P, Burmeister B, Foote M. Radiotherapy for Cutaneous Melanoma: Current and Future Applications. Future Oncol (2015) 11:525-34. doi: $10.2217 /$ fon. 14.300

46. Orth M, Lauber K, Niyazi M, Friedl AA, Li M, Maihofer C, et al. Current Concepts in Clinical Radiation Oncology. Radiat Environ Biophys (2014) 53:1-29. doi: 10.1007/s00411-013-0497-2
47. Triantopoulou S, Efstathopoulos E, Platoni K, Uzunoglou N, Kelekis N, Kouloulias V. Radiotherapy in Conjunction With Superficial and Intracavitary Hyperthermia for the Treatment of Solid Tumors: Survival and Thermal Parameters. Clin Transl Oncol (2013) 15:95-105. doi: 10.1007/ s12094-012-0947-3

48. Maueroder C, Munoz LE, Chaurio RA, Herrmann M, Schett G, Berens C. Tumor Immunotherapy: Lessons From Autoimmunity. Front Immunol (2014) 5:212. doi: 10.3389/fimmu.2014.00212

49. Obeid M, Tesniere A, Ghiringhelli F, Fimia GM, Apetoh L, Perfettini JL, et al. Calreticulin Exposure Dictates the Immunogenicity of Cancer Cell Death. Nat Med (2007) 13:54-61. doi: 10.1038/nm1523

50. Zitvogel L, Casares N, Pequignot MO, Chaput N, Albert ML, Kroemer G. Immune Response Against Dying Tumor Cells. Adv Immunol (2004) 84:13179. doi: 10.1016/S0065-2776(04)84004-5

51. Wang Q, Ju X, Zhou Y, Chen K. Necroptotic Cells Release Find-Me Signal and are Engulfed Without Proinflammatory Cytokine Production. In Vitro Cell Dev Biol Anim (2015) 51:1033-9. doi: 10.1007/s11626-015-9926-7

52. Wyllie AH, Kerr JF, Currie AR. Cell Death: The Significance of Apoptosis. Int Rev Cytol (1980) 68:251-306. doi: 10.1016/S0074-7696(08)62312-8

53. Butkevich OM, Vinogradova TL. [Clinical Aspects and Diagnosis of Infectious Endocarditis]. Kardiologiia (1990) 30:96-100.

54. Garg AD, Romano E, Rufo N, Agostinis P. Immunogenic Versus Tolerogenic Phagocytosis During Anticancer Therapy: Mechanisms and Clinical Translation. Cell Death Differentiation (2016) 23:938-51. doi: 10.1038/ cdd. 2016.5

55. Munoz LE, Gaipl US, Franz S, Sheriff A, Voll RE, Kalden JR, et al. SLE-a Disease of Clearance Deficiency? Rheumatol (Oxford) (2005) 44:1101-7. doi: 10.1093/rheumatology/keh693

56. Gaipl US, Kuenkele S, Voll RE, Beyer TD, Kolowos W, Heyder P, et al. Complement Binding is an Early Feature of Necrotic and a Rather Late Event During Apoptotic Cell Death. Cell Death Differentiation (2001) 8:327-34. doi: 10.1038/sj.cdd.4400826

57. Matzinger P. The Danger Model: A Renewed Sense of Self. Science (2002) 296:301-5. doi: 10.1126/science.1071059

58. Munoz LE, Lauber K, Schiller M, Manfredi AA, Herrmann M. The Role of Defective Clearance of Apoptotic Cells in Systemic Autoimmunity. Nat Rev Rheumatol (2010) 6:280-9. doi: 10.1038/nrrheum.2010.46

59. Munoz LE, Janko C, Grossmayer GE, Frey B, Voll RE, Kern P, et al. Remnants of Secondarily Necrotic Cells Fuel Inflammation in Systemic Lupus Erythematosus. Arthritis Rheumatism (2009) 60:1733-42. doi: 10.1002/art.24535

60. Pei Q, Pan J, Zhu H, Ding X, Liu W, Lv Y, et al. Gemcitabine-Treated Pancreatic Cancer Cell Medium Induces the Specific CTL Antitumor Activity by Stimulating the Maturation of Dendritic Cells. Int Immunopharmacol (2014) 19:10-6. doi: 10.1016/j.intimp.2013.12.022

61. Lin TJ, Lin HT, Chang WT, Mitapalli SP, Hsiao PW, Yin SY, et al. ShikoninEnhanced Cell Immunogenicity of Tumor Vaccine is Mediated by the Differential Effects of DAMP Components. Mol Cancer (2015) 14:174. doi: 10.1186/s12943-015-0435-9

62. Dickerson EB, Dreaden EC, Huang X, El-Sayed IH, Chu H, Pushpanketh S, et al. Gold Nanorod Assisted Near-Infrared Plasmonic Photothermal Therapy (PPTT) of Squamous Cell Carcinoma in Mice. Cancer Lett (2008) 269:57-66. doi: 10.1016/j.canlet.2008.04.026

63. Dreaden EC, Mackey MA, Huang X, Kang B, El-Sayed MA. Beating Cancer in Multiple Ways Using Nanogold. Chem Soc Rev (2011) 40:3391-404. doi: 10.1039/c0cs00180e

64. Schildkopf P, Holmer R, Sieber R, Ott OJ, Janko C, Mantel F, et al. Hyperthermia in Combination With X-Irradiation Induces Inflammatory Forms of Cell Death. Autoimmunity (2009) 42:311-3. doi: 10.1080/ 08916930902832041

65. Werthmoller N, Frey B, Ruckert M, Lotter M, Fietkau R, Gaipl US. Combination of Ionising Radiation With Hyperthermia Increases the Immunogenic Potential of B16-F10 Melanoma Cells In Vitro and In Vivo. Int J Hyperthermia (2016) 32:23-30. doi: 10.3109/02656736.2015.1106011

66. Tadie JM, Bae HB, Deshane JS, Bell CP, Lazarowski ER, Chaplin DD, et al. Toll-Like Receptor 4 Engagement Inhibits Adenosine 5'-MonophosphateActivated Protein Kinase Activation Through a High Mobility Group Box 1 Protein-Dependent Mechanism. Mol Med (2012) 18:659-68. doi: 10.2119/ molmed.2011.00401 
67. Weng H, Deng Y, Xie Y, Liu H, Gong F. Expression and Significance of HMGB1, TLR4 and NF-Kappab P65 in Human Epidermal Tumors. BMC Cancer (2013) 13:311. doi: 10.1186/1471-2407-13-311

68. Yan HX, Wu HP, Zhang HL, Ashton C, Tong C, Wu H, et al. P53 Promotes Inflammation-Associated Hepatocarcinogenesis by Inducing HMGB1 Release. J Hepatol (2013) 59:762-8. doi: 10.1016/j.jhep.2013.05.029

69. Yang H, Hreggvidsdottir HS, Palmblad K, Wang H, Ochani M, Li J, et al. A Critical Cysteine Is Required for HMGB1 Binding to Toll-Like Receptor 4 and Activation of Macrophage Cytokine Release. Proc Natl Acad Sci U S A (2010) 107:11942-7. doi: 10.1073/pnas.1003893107

70. Kang R, Zhang Q, Zeh HJ3rd, Lotze MT, Tang D. HMGB1 in Cancer: Good, Bad, or Both? Clin Cancer Res (2013) 19:4046-57. doi: 10.1158/10780432.CCR-13-0495

71. Chaurio RA, Munoz LE, Maueroder C, Janko C, Harrer T, Furnrohr BG, et al. The Progression of Cell Death Affects the Rejection of Allogeneic Tumors in Immune-Competent Mice - Implications for Cancer Therapy. Front Immunol (2014) 5:560. doi: 10.3389/fimmu.2014.00560

72. Kazama H, Ricci JE, Herndon JM, Hoppe G, Green DR, Ferguson TA. Induction of Immunological Tolerance by Apoptotic Cells Requires Caspase-Dependent Oxidation of High-Mobility Group Box-1 Protein. Immunity (2008) 29:21-32. doi: 10.1016/j.immuni.2008.05.013

73. Kolaczkowska E, Kubes P. Neutrophil Recruitment and Function in Health and Inflammation. Nat Rev Immunol (2013) 13:159-75. doi: 10.1038/nri3399

74. Rider P, Carmi Y, Guttman O, Braiman A, Cohen I, Voronov E, et al. IL1alpha and IL-1beta Recruit Different Myeloid Cells and Promote Different Stages of Sterile Inflammation. J Immunol (2011) 187:4835-43. doi: 10.4049/ jimmunol.1102048

75. Lee PY, Kumagai Y, Xu Y, Li Y, Barker T, Liu C, et al. IL-1alpha Modulates Neutrophil Recruitment in Chronic Inflammation Induced by Hydrocarbon Oil. J Immunol (2011) 186:1747-54. doi: 10.4049/jimmunol.1001328
76. Hart IR. The Selection and Characterization of an Invasive Variant of the B16 Melanoma. Am J Pathol (1979) 97:587-600.

77. Danciu C, Falamas A, Dehelean C, Soica C, Radeke H, Barbu-Tudoran L, et al. A Characterization of Four B16 Murine Melanoma Cell Sublines Molecular Fingerprint and Proliferation Behavior. Cancer Cell Int (2013) 13:75. doi: 10.1186/1475-2867-13-75

78. Barutello G, Rolih V, Arigoni M, Tarone L, Conti L, Quaglino E, et al. Strengths and Weaknesses of Pre-Clinical Models for Human Melanoma Treatment: Dawn of Dogs' Revolution for Immunotherapy. Int J Mol Sci (2018) 19(3):799. doi: 10.3390/ijms19030799

79. Saleh J. Murine Models of Melanoma. Pathol Res Pract (2018) 214:1235-8. doi: 10.1016/j.prp.2018.07.008

Conflict of Interest: The authors declare that the research was conducted in the absence of any commercial or financial relationships that could be construed as a potential conflict of interest.

Publisher's Note: All claims expressed in this article are solely those of the authors and do not necessarily represent those of their affiliated organizations, or those of the publisher, the editors and the reviewers. Any product that may be evaluated in this article, or claim that may be made by its manufacturer, is not guaranteed or endorsed by the publisher.

Copyright (C) 2021 Podolska, Shan, Janko, Boukherroub, Gaipl, Szunerits, Frey and Muñoz. This is an open-access article distributed under the terms of the Creative Commons Attribution License (CC BY). The use, distribution or reproduction in other forums is permitted, provided the original author(s) and the copyright owner(s) are credited and that the original publication in this journal is cited, in accordance with accepted academic practice. No use, distribution or reproduction is permitted which does not comply with these terms. 